\title{
Effects of agricultural water withdrawal in the fluvial habitat of benthic macroinvertebrates in Chile
}

\section{Efectos de la extracción agrícola del agua en el hábitat fluvial de macroinvertebrados bentónicos en Chile}

\author{
Meyer Guevara-Mora, Pablo Pedreros, Roberto Urrutia and Ricardo Figueroa
}

Centro de Ciencias Ambientales EULA-Chile, Universidad de Concepción, Casilla 160-C, Concepción, Chile e-mail: entomomeyer@gmail.com

Recibido: 20 de mayo de 2015. Aceptado: 09 de febrero de 2016.

Guevara-Mora M., P. Pedreros, R. Urrutia and R. Figueroa. 2016. Effects of agricultural water withdrawal in the fluvial habitat of benthic macroinvertebrates in Chile. Hidrobiológica 26 (3): 373-382.

\begin{abstract}
Background. The climatic and geographic characteristics of Central Chile allow the concentration of high water demand from agricultural activities in low order rivers. Changes in the hydrologic regime of these rivers should affect the habitat availability of endemic benthic macroinvertebrates. However, the impact of water diversion in the Chilean rivers is poorly understood. Goals. We want to determine the effects of water abstraction in the habitat of benthic macroinvertebrates with biotic indices. Methods. We sampled nutrients, macroinvertebrates, and morphological characteristics of three rivers affected by agricultural water extractions in the Itata basin (Chile). We assess the habitat alteration and benthic macroinvertebrate assemblage through the measurement of depth, current velocity, Froude number, wetted width/depth ratio, dissolved oxygen, and biotic indices. Results. Traditional methods of constructing the weirs affect the water level in the sampling sites. Most of the habitat parameters shows variation between the control and impact sampling sections, but only Shannon and Simpson diversity indices were statistical different. Conclusions. The increase in taxonomical resolution of benthic macroinvertebrates in the Mediterranean zone of Chile could improve detection of environmental impacts of water extraction. We suggest the use of biological traits in order to determine specific relationships between water withdrawals and environmental changes in low order rivers of Chile affected by water extraction.
\end{abstract}

Key words: Agriculture, aquatic insects, flow, stream disturbance, water extractions.

\section{RESUMEN}

Antecedentes. Las características climáticas y geográficas de Chile Central permiten la concentración de alta demanda de agua para las actividades agrícolas en los ríos de bajo orden. Los cambios en el régimen hidrológico de estos ríos podrían afectar la disponibilidad de hábitat para las especies endémicas de macroinvertebrados bentónicos. Sin embargo, el impacto de la extracción del agua en ríos de Chile ha sido poco estudiado en esta área. Objetivos. Se determinaron los efectos de la extracción del agua en el hábitat de los macroinvertebrados bentónicos mediante índices bióticos. Métodos. Se colectaron muestras de nutrientes y de las características morfológicas de 3 ríos afectados por las extracciones de agua en la cuenca del Itata, Chile para establecer el efecto en los ensambles de macroinvertebrados bentónicos. Evaluamos la alteración del hábitat y los cambios en la comunidad de macroinvertebrados bentónicos a través de la medición de la profundidad, velocidad de la corriente, número de Froude, ancho del río/profundidad, oxígeno disuelto, índices bióticos y de diversidad. Resultados. Los métodos tradicionales para la construcción de las estructuras de derivación de caudal afectaron el nivel del agua en los sitios de muestreo. La mayoría de los parámetros relacionados con el hábitat variaron entre los puntos de control e impacto, pero únicamente los índices de Shannon y Simpson mostraron diferencias estadísticamente significativas. Conclusiones. El aumento en la resolución taxonómica para la determinación de los macroinvertebrados bentónicos de la zona mediterránea de Chile podría favorecer la detección de los impactos ambientales asociados a la extracción de agua. Sugerimos el uso de rasgos biológicos para poder establecer relaciones específicas entre las extracciones de agua y los cambios ambientales en los ríos de orden bajo de Chile.

Palabras clave: Agricultura, caudal, extracción de agua, insectos acuáticos, perturbaciones en ríos. 


\section{INTRODUCTION}

The Mediterranean central area of Chile is a hot spot for biodiversity conservation (Myers et al., 2000; Valdovinos, 2008) due to the high diversity and species richness of some taxonomic groups like Plecoptera, Trichoptera, and Ephemeroptera (Figueroa et al., 2013; Palma \& Figueroa, 2008). In this area, physiographic and climatic conditions promote fluvial habitat diversity that enhances the fluvial habitat patchiness in low order rivers (Andreoli et al., 2012). However, the concentration of agricultural activities threatens the natural hydrologic regime of the rivers (Bonada \& Resh, 2013; Figueroa et al., 2013; Habit et al., 2006).

Agriculture activities mainly increase the concentrations of nitrate and phosphorus on the aquatic ecosystems (Dudgeon et al., 2006; Vörösmarty et al., 2010) in several basins of the central zone of Chile. The actual concentration of these compounds do not represent a hazard condition (Pizarro et al., 2010; Ribbe et al., 2008), but increasing demand of water in agriculture should modify the flow and hydromorphological characteristics of low order rivers (Andreoli et al., 2012).

The natural flow regime is fundamental in low order river conservation, because it produces shifting habitat conditions (Poff et al., 1997; Stanford et al., 2005; Townsend et al., 1997), which increases the aquatic biodiversity (Death 2010; Townsend et al., 1997). Most of the scientific literature about flow alteration in Chilean rivers focuses on the relation between aquatic fauna (fish assemblage) and hydroelectric dams (Andreoli et al., 2012; García et al., 2011; Habit et al., 2007). For example, Habit et al. (2007), detected changes in the fish assemblage by the construction and operation of the Laja and Rucúe dams, since irrigation water withdrawals in the Laja River tends to increase the perturbation on the river's ecosystem. Moreover, García et al. (2011), detected changes in the hydraulic characteristics (velocity and depth) of the Biobio River due to the daily peaks of electric demand during summer with possible effects on fish feeding behavior or spatial distribution.

Similar to other world regions (Bonada \& Resh, 2013; Chessman et al., 2011; Dewson et al., 2007a), in the central zone of Chile many irrigation users collect water from low order rivers during their base flows of spring and summer (Figueroa et al., 2007). Thus, the aim of our study was to determine the effects of water abstraction on the habitat of benthic macroinvertebrates in low order rivers of Chile's central zone. We also determined the relationship between macroinvertebrate biotic indices (CHSIGNAL and EPT) and flow reduction to improve the conservation of Mediterranean rivers in Chile.

\section{MATERIAL AND METHODS}

Characteristics of the sampling sites. We selected 3 sampling sites (Dehesa, Recinto, and Marchant) with different regimes of water abstraction in the Itata basin. Due to the position of the diversion points in private lands and geographical access, we were only able to collect information in the selected points. All the sampling sites are located in different low order rivers of the Itata basin, a Mediterranean climate area with annual average temperature of $14.1^{\circ} \mathrm{C}$ and $1550 \mathrm{~mm}$ of precipitation (Di Castri \& Hajek, 1976; Urrutia et al., 2009a).

Native forests of evergreen Drimys winteri and Nothophagus spp. are common in the foothills, while agriculture landscapes prevail in the central valley (Figueroa et al., 2013). According to Figueroa et al. (2007), and Debels et al. (2005), there is good water quality in the watershed; the sewage discharge of the city of Chillán is the only factor related to nutrient enrichment at a lower altitude (see Fig.1).

All sampling sites have their channel morphology modified by the construction of small weirs with boulders, sand bags, or wood. Steel doors and sand bags partially seal the irrigation channels during the winter flow, and avoid inundation of agricultural field in Dehesa and Marchant sites. The riverbed is composed of an alternate combination of cobbles with riffle and pool, a common characteristic of the rivers in Chile's central zone (Andreoli et al., 2012; Figueroa et al., 2013).

Habitat sampling. At all sampling sites, we selected a $100 \mathrm{~m}$ reach section before (control) and after (impact) the weirs. According to Dewson et al. (2007c), $100 \mathrm{~m}$ reach is enough to observe the effects of water abstraction and there is no chance of flow recovering by groundwater. To characterize the trophic status of the sampling sites, we collected water samples for $\mathrm{NO}_{2}(\mathrm{mg} / \mathrm{L}), \mathrm{NO}_{3}^{-}(\mathrm{mg} / \mathrm{L}), \mathrm{NH}_{4}{ }^{+}(\mathrm{mg} / \mathrm{L})$, Organic $\mathrm{N}(\mathrm{mg} / \mathrm{L})$, Total $\mathrm{N}$ (mg/L), Organic P (mg/L), Total P $(\mathrm{mg} / \mathrm{L}), \mathrm{PO}_{4}{ }^{3-}(\mathrm{mg} / \mathrm{L})$, and Suspended solids (mg/L) analysis in March (low flow) and August 2013 (high flow). Water samples were kept cold until their analyses in the Environmental Chemistry Laboratory, EULA Center for Environmental Sciences, University of Concepción (Eaton et al., 2005).

We recorded the habitat characteristics (water depth, river wetted width, current velocity) and in situ chemical parameters in six random points on every reach during the low flow period (October, December 2012, and March 2013) and high flow period (August 2013). The selected in situ physico-chemical parameters were temperature, conductivity (Hanna Instruments HI 9835), pH (Hanna Instruments HI 9126), and dissolved oxygen (Hanna Instruments HI 9146).

Stream discharge $(\mathrm{L} / \mathrm{s})$ was determined in control and impact reach by 10 equidistant measurements of depth and current velocity ( 0.6 depth) with a Gurley 1100.1 Flow Velocity Indicator (Gore, 2007).

Macroinvertebrate sampling. We sampled benthic macroinvertebrate community for each stream reach section on all sampling dates. All the macroinvertebrate sampling sites were near to habitat sampling. A Surber sampler (mesh size $=250 \mu \mathrm{m}, 0.09 \mathrm{~m}^{2}$ area) was placed in 6 random points to remove organisms. The organisms collected were fixed in $95 \%$ alcohol and transported to Bioindicators Laboratory at the EULA Center for Environmental Sciences. We identified the macroinvertebrates to the family level with the available taxonomic literature (Domínguez et al., 2006; Stark et al., 2009). A higher taxonomic resolution was not possible due to the scarce taxonomic knowledge of the Mediterranean area (Figueroa et al., 2013) and the small size of most of the organisms (e.g. Gripopterygidae).

Biodiversity indices of Shannon ( $\left.\mathrm{H}^{\prime}\right)$ and Simpson (D'), total abundance, and family richness were determined to describe the changes in macroinvertebrate assemblage between control and impact reach sections.

In order to assess the sensitivity of biotic indices to water extraction, we selected the ChSIGNAL and EPT index. The ChSIGNAL is an adaptation of the SIGNAL index (Chessman, 2003) with benthic macroinvertebrates of Chile (see Figueroa et al., 2007). The EPT index corresponds to the count of families from the Ephemeroptera, Plecoptera, and Trichoptera orders collected at the sampling sites (McKay \& King, 2006). 


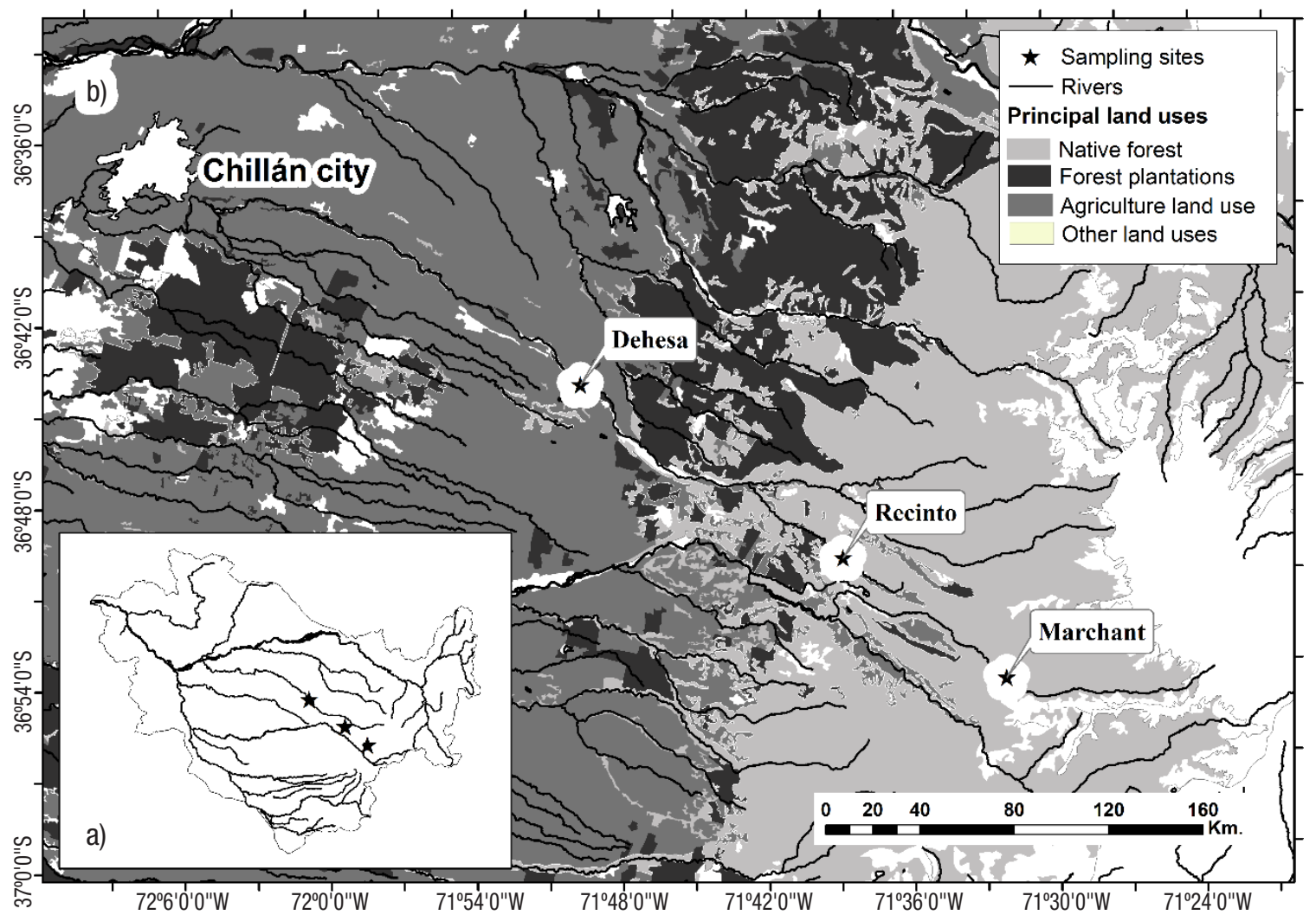

Figures 1a-b. Location of the sampling sites in the Itata basin (a) and principal land use (b) in the mediterranean central area of Chile.

Statistical analysis. To assess the relation between habitat variables and flow (L/s), a Pearson correlation was used $(R>0.8 ; p<0.05)$. Furthermore, two data matrices were used: 1) aggregated data of all the sites in order to detect a general response of the streams of the area, and 2) separated data of every site to define specific responses to low flow conditions.

Statistical difference between the control and impact reach sections in low flow were calculated with the Student T-test $(p<0.05)$, but the differences between low flow (spring/summer) and high flow (winter) conditions were calculated with ANOVA BACI design (Downes, 2002). In the BACl model for statistical differences, $B$ corresponds to each of the sampling dates in spring or summer, $A$ is the sampling date in high flow period (winter), $C$ refers to control reach sections, and I is the impact reach sections. Therefore, a significant difference in the BA $\mathrm{x} \mathrm{Cl}$ indicated that the change in the environmental parameter is associated with water withdrawals (Downes, 2002).

The relationship between habitat parameters, biotic and diversity indices was established with a Multiple Linear Regression analysis, Akaike Information Criterion, and the Forward/Backward selection in the MASS statistical package (Venables \& Ripley, 2002). Then, the most important environmental predictor was determined from the previous selected variables with all-subsets by a regression model in LEAPS $R$ statistical package $(p<0.05)$.

The differences in the macroinvertebrate community assemblage were determined with ADONIS statistical analysis (Anderson, 2001).
Comparisons were made using the Bray Curtis similarity matrix. Previously, abundance data were transformed to $\log _{10}(x+1)$ in order to reduce the contribution of the families with greater numerical representation in the samples (Anderson et al., 2006; Gauch, 1982). IndVal (Dufrene \& Legendre, 1997) established the most important families in terms of the differences between control and impact reach sections. The IndVal method considers the abundance and relative frequency of the different families in each sample in order to assign an indicator value and a probability $p$ derived from the Monte Carlo permutation.

\section{RESULTS}

The weirs modified the discharge in all the sampling sites. The highest summer flow reduction was registered in Dehesa (97.7\%), while the lowest was in Recinto (26.1\%), both in December 2012. In August 2013 (winter period), we observed closed weirs in Marchant and Dehesa; however, it was possible to record some water withdrawals (Table 1). Only water depth (R: $0.85 ; p<0.05)$, current velocity (R: $0.84 ; p<0.05)$, and conductivity (R: $0.65 ; p<0.05)$ showed correlation with the flow measurements. According to the chemical characteristics, Dehesa and Recinto showed oligotrophic conditions in low and high flow periods (< $0.03 \mathrm{mgL}^{-1} \mathrm{NH}_{4}^{+},<0.2 \mathrm{mgL}^{-1} \mathrm{NO}_{3}^{-},<0.04 \mathrm{mgL}^{-1} \mathrm{PO}_{4}{ }^{3-}$ ). In Marchant the concentration of $\mathrm{NO}_{3}^{-}\left(0.384 \mathrm{mgL}^{-1}\right)$ and $\mathrm{PO}_{4}{ }^{3-}\left(0.13 \mathrm{mgL}^{-1}\right)$ tends to decrease in the high flow period $\left(0.293 \mathrm{mgL}^{-1} \mathrm{NO}_{3}^{-}\right.$and $0.06 \mathrm{mgL}^{-1}$ $\mathrm{PO}_{4}{ }^{3-}$ ) (Table 2). 
Table 1. Temporal flow variation (L/s) in control and impact reach sections of the sampling sites.

\begin{tabular}{|c|c|c|c|c|c|}
\hline \multicolumn{2}{|c|}{ Site / Reach section } & $\begin{array}{c}\text { October } \\
2012\end{array}$ & $\begin{array}{c}\text { December } \\
2012\end{array}$ & $\begin{array}{l}\text { March } \\
2013\end{array}$ & $\begin{array}{c}\text { August } \\
2013\end{array}$ \\
\hline \multirow{3}{*}{ Dehesa } & Control & 110.8 & 323.9 & 368.6 & 3256.3 \\
\hline & Impact & 23.6 & 34.0 & 33.2 & 2960.8 \\
\hline & $\%$ of flow reduction & 78.7 & 89.5 & 91.0 & 9.1 \\
\hline \multirow{3}{*}{ Recinto } & Control & 217.2 & 92.8 & 54.4 & 377.6 \\
\hline & Impact & 135.5 & 68.6 & 22.9 & 359.8 \\
\hline & $\%$ of flow reduction & 37.6 & 26.1 & 57.9 & 4.7 \\
\hline \multirow{3}{*}{ Marchant } & Control & 1806.7 & 1245.7 & 1018.5 & 2357.5 \\
\hline & Impact & 1108.5 & 661.8 & 728.4 & 2108.2 \\
\hline & $\%$ of flow reduction & 38.6 & 46.9 & 28.5 & 11.8 \\
\hline
\end{tabular}

Most of the habitat variables showed variation between control and impact reach sections (Table 3). The coefficient of variation (control <impact) was higher than $10 \%$ for depth, current velocity, wetted width/depth ratio, Froude number, richness, abundance, and EPT. The t-test detected statistical differences $(p<0.05)$ for dissolved oxygen, depth, Froude number, current velocity, wetted width/depth ratio, Shannon and Simpson's diversity (Fig. 2). Neither EPT nor ChSIGNAL biotic indices showed statistical differences between control and impact reach sections (Fig. 2).

Comparing low and high flow sampling dates with ANOVA BACI design, only current velocity showed significant differences in 2 different sampling dates (October 2012 and March 2013). No statistical differences were detected for water temperature, wetted width, and hydraulic Froude number in December 2012 (Table 4). According to linear regression models, habitat and chemical parameters were good predictors of community assemblages; however, it was not possible to establish a significative model with the Simpson diversity index. The best significative model $\left(\mathrm{R}^{2}=0.37\right)$ was determined for ChSIGNAL index $(\mathrm{pH}$ and $\mathrm{DO}$ ), while the lower explanatory power of the models was recorded for Shannon diversity $\left(R^{2}=0.19\right)$ (Table 5).
The total abundance of benthic macroinvertebrate was 41133 individuals (3173 individuals $/ \mathrm{m}^{2}$ ), distributed in 10 orders and 49 families. The order with the highest abundance was Diptera $(n=16465)$, followed by Ephemeroptera ( $n=7371)$, Trichoptera $(n=7122)$, and Plecoptera $(n=6486)$. The highest abundance of Baetidae, Leptophlebiidae (Ephemeroptera), Gripopterygidae, and Notonemouridae (Plecoptera) occurred during low flow. Significant differences in macroinvertebrate assemblage were established in October and December 2012 (low and high flow), while in March, differences were determined for the control and impact reach sections (Table 6). The IndVal test determined that Notonemouridae (Plecoptera; IndVal: 0.385, p: 0.004) was a good indicator for impact reach sections, while Diamphipnoidea (Plecoptera; IndVal: 0.630, p: 0.002) or Glossosomatidae (Trichoptera; IndVal: 0.394, $p$ : 0.036) were a good indicator for the control reaches of all the sites.

\section{DISCUSSION}

In this study, diversion structures in the rivers produced a contraction of the fluvial habitat, low variation of chemical characteristics, and changes in the macroinvertebrate community assemblage. To our knowledge, this is the first study that determines the impact of irrigation withdrawals in the Chilean rivers, although irrigation agriculture consumes $85 \%$ of available water resources and modifies modifies natural flow regimen (Figueroa et al., 2013).

The natural flow has direct influence in the water chemical composition of the rivers (Bunn \& Arthington, 2002; Dewson et al., 2007a; Larned et al., 2010). Particularly, it has been reported that scarce water conditions produce temporal and spatial changes in nitrogen compounds (Caruso, 2002; Dahm et al., 2003; Von Schiller et al., 2011), therefore similar trends are expected in rivers with intense agricultural water withdrawals. However, in this study we detected no significant chemical changes in the nutrients that could be related to good river conservation in the area (Debels et al., 2005; Figueroa et al., 2007; Urrutia et al., 2009b). Nor could we find a traditional river damning method that does not promote changes in the ionic composition of the surface waters by anoxic conditions (Ahearn et al., 2005; Friedl \& Wüest, 2002).

Table 2. Concentration of nutrient and suspended solids for the sampling sites on the Itata basin, Chile, in low (March 2013) and high flow (August 2013) hydrological conditions (Values in bold = Under detection limit).

\begin{tabular}{|c|c|c|c|c|c|c|c|c|c|c|c|}
\hline Date & Site & Reach & $\begin{array}{c}\mathrm{NO}_{2} \\
(\mathrm{mg} / \mathrm{L})\end{array}$ & $\begin{array}{c}\mathrm{NO}_{3}^{-} \\
(\mathrm{mg} / \mathrm{L})\end{array}$ & $\begin{array}{l}\mathrm{NH}_{4}^{+} \\
(\mathrm{mg} / \mathrm{L}) \\
\end{array}$ & $\begin{array}{c}\text { Organic N } \\
(\mathrm{mg} / \mathrm{L})\end{array}$ & $\begin{array}{l}\text { Total N } \\
(\mathrm{mg} / \mathrm{L})\end{array}$ & $\begin{array}{c}\text { Organic P } \\
(\mathrm{mg} / \mathrm{L})\end{array}$ & $\begin{array}{l}\text { Total P } \\
\text { (mg/L) }\end{array}$ & $\begin{array}{l}\mathrm{PO}_{4}^{3-} \\
(\mathrm{mg} / \mathrm{L})\end{array}$ & $\begin{array}{c}\text { Suspended } \\
\text { solids (mg/L) }\end{array}$ \\
\hline \multirow{6}{*}{ March } & \multirow{2}{*}{ Marchant } & Control & 0.015 & 0.384 & 0.03 & 0.04 & 0.15 & 0.04 & 0.12 & 0.13 & 1.0 \\
\hline & & Impact & 0.015 & 0.384 & 0.03 & 0.06 & 0.17 & 0.03 & 0.11 & 0.13 & 1.0 \\
\hline & \multirow{2}{*}{ Recinto } & Control & 0.077 & 0.039 & 0.03 & 0.03 & 0.09 & 0.02 & 0.03 & 0.04 & 1.0 \\
\hline & & Impact & 0.076 & 0.038 & 0.03 & 0.03 & 0.09 & 0.01 & 0.02 & 0.04 & 1.0 \\
\hline & \multirow{2}{*}{ Dehesa } & Control & 0.015 & 0.025 & 0.03 & 0.04 & 0.07 & 0.01 & 0.04 & 0.04 & 4.3 \\
\hline & & Impact & 0.015 & 0.037 & 0.03 & 0.04 & 0.08 & 0.01 & 0.05 & 0.04 & 5.0 \\
\hline \multirow{6}{*}{ August } & \multirow{2}{*}{ Marchant } & Control & 0.015 & 0.293 & 0.03 & 0.01 & 0.10 & 0.04 & 0.06 & 0.06 & 1.2 \\
\hline & & Impact & 0.015 & 0.202 & 0.03 & 0.03 & 0.10 & 0.03 & 0.05 & 0.05 & 1.0 \\
\hline & \multirow{2}{*}{ Recinto } & Control & 0.015 & 0.139 & 0.03 & 0.01 & 0.06 & 0.01 & 0.02 & 0.04 & 2.0 \\
\hline & & Impact & 0.015 & 0.410 & 0.03 & 0.01 & 0.12 & 0.01 & 0.01 & 0.04 & 2.3 \\
\hline & \multirow{2}{*}{ Dehesa } & Control & 0.015 & 0.101 & 0.03 & 0.04 & 0.09 & 0.01 & 0.01 & 0.04 & 1.0 \\
\hline & & Impact & 0.015 & 0.121 & 0.03 & 0.03 & 0.09 & 0.01 & 0.01 & 0.04 & 1.0 \\
\hline
\end{tabular}



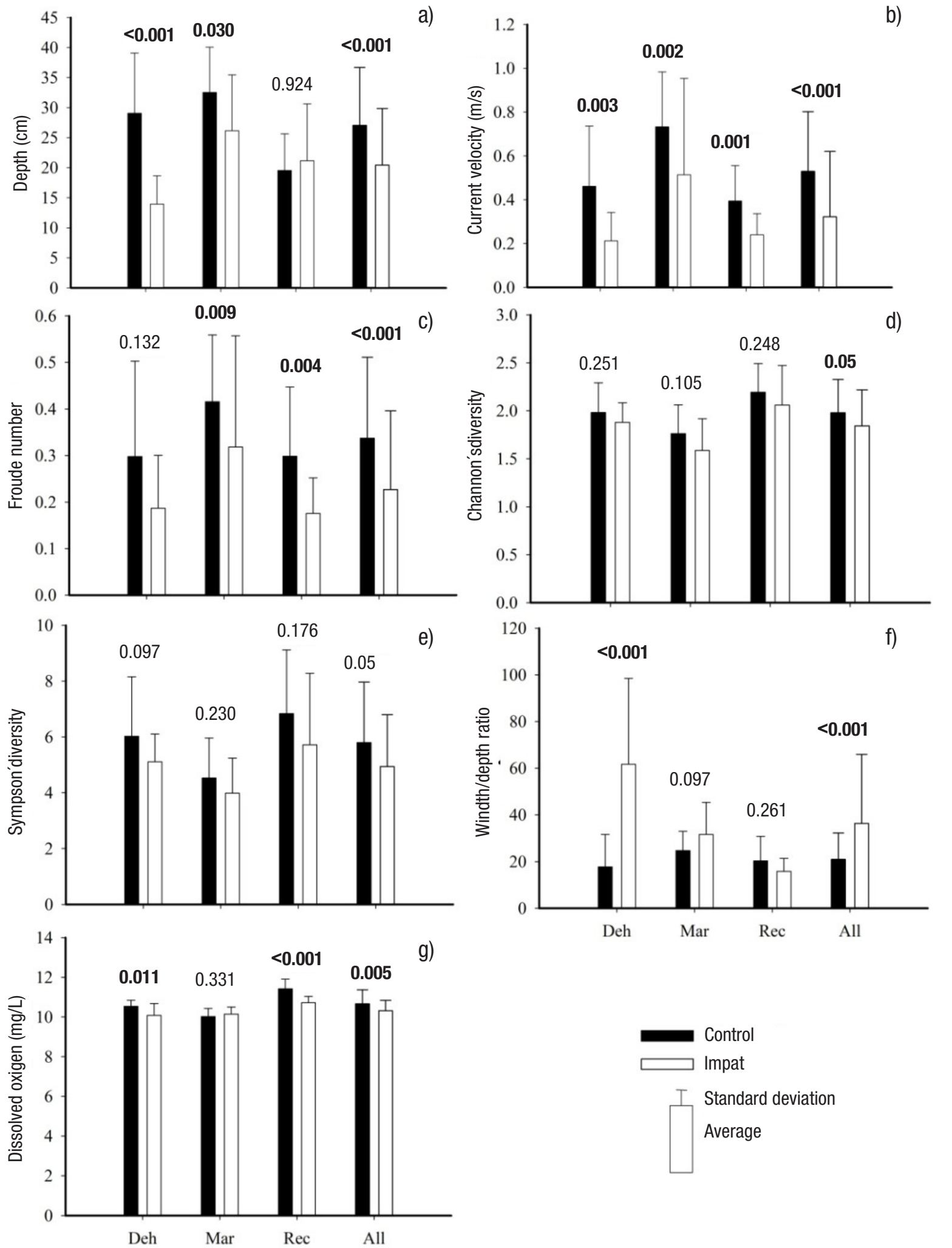

b)

d)

Figures 2a-g. Habitat parameters and diversity indices with $T$ test statistically significant differences $(p<0.05)$ between control and impact reach sections in low fflow period on Itata basin, Chile. (Deh = Dehesa; Mar = Marchant; Rec = Recinto; All = aggregation of all the sites). 
Table 3. Mean $(\overline{\mathrm{x}})$, standard deviation (SD), and variation coefficient (CV) of the habitat characteristics and community assemblage descriptors in control and impact reach sections in low flow sampling dates, in central area of Chile.

\begin{tabular}{|c|c|c|c|c|c|c|c|c|c|}
\hline \multirow{2}{*}{ Parameters } & & \multicolumn{2}{|c|}{ Recinto } & \multicolumn{2}{|c|}{ Marchant } & \multicolumn{2}{|c|}{ Dehesa } & \multicolumn{2}{|c|}{ All sites } \\
\hline & & Control & Impact & Control & Impact & Control & Impact & Control & Impact \\
\hline \multirow[t]{2}{*}{ Dissolved oxygen (mg/L) } & $\begin{array}{c}\overline{\mathrm{x}} \\
\mathrm{SD}\end{array}$ & $\begin{array}{c}11.42 \\
0.49\end{array}$ & $\begin{array}{c}10.72 \\
0.32\end{array}$ & $\begin{array}{c}10.02 \\
0.41\end{array}$ & $\begin{array}{c}10.15 \\
0.35\end{array}$ & $\begin{array}{c}10.54 \\
0.31\end{array}$ & $\begin{array}{c}10.08 \\
0.60\end{array}$ & $\begin{array}{c}10.66 \\
0.71\end{array}$ & $\begin{array}{c}10.31 \\
0.52\end{array}$ \\
\hline & CV (\%) & 4 & 3 & 4 & 3 & 3 & 6 & 7 & 5 \\
\hline \multirow[t]{3}{*}{ Temperature $\left({ }^{\circ} \mathrm{C}\right)$} & $\bar{x}$ & 10.11 & 10.88 & 13.83 & 13.69 & 16.29 & 15.85 & 13.41 & 13.47 \\
\hline & SD & 0.99 & 2.41 & 0.71 & 0.63 & 2.94 & 3.09 & 3.13 & 3.04 \\
\hline & CV (\%) & 10 & 22 & 5 & 5 & 18 & 19 & 23 & 23 \\
\hline \multirow[t]{3}{*}{$\mathrm{pH}$} & $\bar{x}$ & 7.23 & 7.52 & 7.81 & 7.80 & 7.74 & 7.70 & 7.59 & 7.67 \\
\hline & SD & 0.22 & 0.16 & 0.27 & 0.31 & 0.22 & 0.13 & 0.35 & 0.24 \\
\hline & CV (\%) & 3 & 2 & 3 & 4 & 3 & 2 & 4 & 3 \\
\hline \multirow[t]{3}{*}{ Conductivity $\left(\mu \mathrm{Scm}^{-1}\right)$} & $\overline{\mathrm{x}}$ & 36.56 & 38.41 & 228.7 & 229.2 & 118.4 & 118.9 & 127.9 & 128.8 \\
\hline & SD & 1.69 & 4.31 & 23.22 & 22.18 & 17.13 & 16.62 & 81.16 & 80.53 \\
\hline & CV (\%) & 5 & 11 & 10 & 10 & 14 & 14 & 63 & 62 \\
\hline \multirow[t]{3}{*}{ Wetted width (cm) } & $\overline{\mathrm{x}}$ & 358.2 & 295.3 & 753.6 & 717.9 & 459.2 & 716.0 & 523.6 & 576.4 \\
\hline & SD & 145.65 & 68.04 & 93.7 & 58.54 & 272.4 & 231.3 & 249.2 & 245.0 \\
\hline & CV (\%) & 41 & 23 & 12 & 8 & 59 & 32 & 47 & 42 \\
\hline \multirow[t]{3}{*}{ Depth (cm) } & $\overline{\mathrm{x}}$ & 19.53 & 21.17 & 32.53 & 26.14 & 29.06 & 13.94 & 27.04 & 20.42 \\
\hline & SD & 6.09 & 9.46 & 7.51 & 9.29 & 10.01 & 4.71 & 9.64 & 9.43 \\
\hline & CV (\%) & 31 & 45 & 23 & 35 & 34 & 34 & 36 & 46 \\
\hline \multirow[t]{3}{*}{ Current velocity $\left(\mathrm{m}^{3} \mathrm{~s}^{-1}\right)$} & $\overline{\mathrm{x}}$ & 0.39 & 0.24 & 0.73 & 0.51 & 0.46 & 0.21 & 0.53 & 0.32 \\
\hline & SD & 0.16 & 0.09 & 0.25 & 0.43 & 0.27 & 0.13 & 0.27 & 0.30 \\
\hline & CV (\%) & 41 & 40 & 34 & 85 & 60 & 61 & 51 & 92 \\
\hline \multirow[t]{3}{*}{ Width/depth ratio } & $\bar{x}$ & 20.33 & 15.77 & 24.73 & 31.64 & 17.71 & 61.68 & 20.92 & 36.36 \\
\hline & SD & 10.50 & 5.59 & 8.20 & 13.72 & 13.94 & 36.82 & 11.31 & 29.57 \\
\hline & CV (\%) & 52 & 35 & 33 & 43 & 78 & 60 & 54 & 81 \\
\hline \multirow[t]{3}{*}{ Froude \# } & $\bar{x}$ & 0.30 & 0.17 & 0.41 & 0.23 & 0.30 & 0.18 & 0.34 & 0.23 \\
\hline & SD & 0.14 & 0.07 & 0.14 & 0.75 & 0.20 & 0.11 & 0.17 & 0.17 \\
\hline & CV (\%) & 50 & 43 & 34 & 75 & 69 & 61 & 51 & 74 \\
\hline \multirow[t]{3}{*}{ Richness } & $\bar{x}$ & 16.44 & 16.11 & 13.3 & 11.33 & 12.56 & 10.94 & 14.09 & 12.80 \\
\hline & SD & 2.68 & 4.24 & 3.40 & 4.10 & 2.38 & 2.66 & 3.28 & 4.36 \\
\hline & CV (\%) & 16 & 26 & 26 & 36 & 18 & 24 & 23 & 34 \\
\hline \multirow[t]{3}{*}{ Abundance } & $\bar{x}$ & 265.4 & 145.1 & 289.5 & 387 & 195.7 & 108.8 & 250.2 & 213.7 \\
\hline & SD & 197.05 & 90.12 & 239.5 & 352.4 & 212 & 88.19 & 216.7 & 246 \\
\hline & CV (\%) & 74 & 62 & 83 & 91 & 100 & 81 & 87 & 100 \\
\hline \multirow[t]{3}{*}{ Shannon (H') } & $\bar{x}$ & 2.19 & 2.06 & 1.76 & 1.59 & 1.98 & 1.88 & 1.98 & 1.84 \\
\hline & $\mathrm{SD}$ & 0.29 & 0.41 & 0.30 & 0.33 & 0.31 & 0.20 & 0.35 & 0.38 \\
\hline & CV (\%) & 14 & 20 & 17 & 21 & 16 & 10 & 17 & 20 \\
\hline \multirow[t]{3}{*}{ Simpson (D) } & $\bar{x}$ & 6.84 & 5.72 & 4.53 & 3.98 & 6.02 & 5.11 & 5.80 & 4.93 \\
\hline & $\mathrm{SD}$ & 2.28 & 2.56 & 1.43 & 1.26 & 2.13 & 0.99 & 2.17 & 1.85 \\
\hline & CV (\%) & 33 & 45 & 31 & 32 & 35 & 19 & 37 & 38 \\
\hline \multirow[t]{3}{*}{ EPT } & $\bar{x}$ & 8.28 & 8.11 & 6.27 & 5.66 & 4.00 & 3.89 & 6.18 & 5.89 \\
\hline & SD & 1.60 & 2.37 & 1.96 & 2.40 & 1.08 & 1.32 & 2.35 & 2.69 \\
\hline & CV (\%) & 19 & 29 & 31 & 42 & 27 & 34 & 38 & 46 \\
\hline \multirow[t]{3}{*}{ ChSIGNAL } & $\bar{x}$ & 6.68 & 6.45 & 5.63 & 5.37 & 6.10 & 6.14 & 6.14 & 5.99 \\
\hline & SD & 0.48 & 0.71 & 0.60 & 0.49 & 0.48 & 0.53 & 0.67 & 0.74 \\
\hline & CV (\%) & 7 & 11 & 11 & 9 & 8 & 9 & 11 & 12 \\
\hline
\end{tabular}


Table 4. Summary of ANOVA test for BA x Cl comparison in control and reach sections of all the sampling sites, in central area of Chile. (Itata basin).

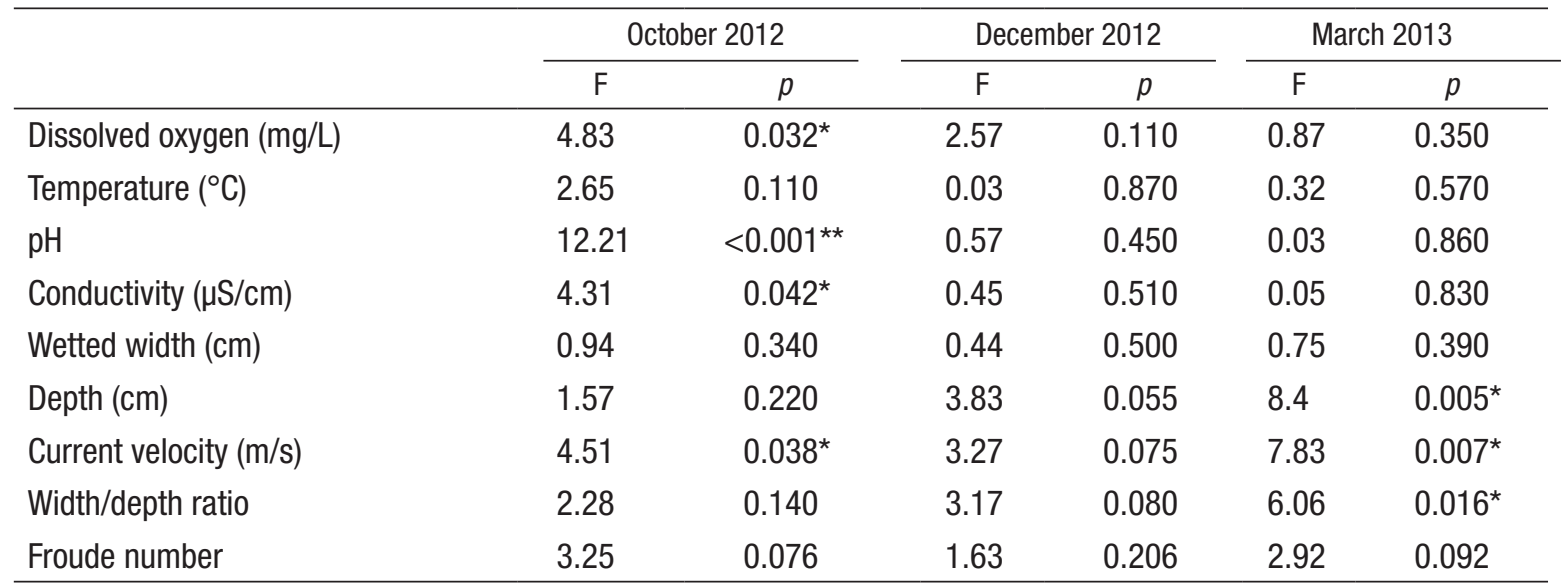

${ }^{*}=p<0.05 .{ }^{* *}=p<0.01$

Dissolved oxygen was the only parameter that showed statistical differences between control and impact sampling sites. Several authors indicate that D0 concentration decreases in river water withdrawals (Dewson et al., 2007b; McKay \& King, 2006) related to reduced turbulence conditions or increasing heating exposure (Brown et al., 2012; Chessman et al., 2010; Dewson et al., 2007b). At the sampling sites, dense riparian forest protected the rivers from increased heating, and low depth/wide values can explain the lack of differences in the thermal regimen (Pedreros et al., 2013).

The principal indicator of turbulence perturbation in our study was the Froude number. The Froude number is closely related to current velocity and water depth, and is considered a good indicator of the hydraulic and microhabitat characteristics for the benthic macroinvertebrates (Brooks et al., 2005; Allan \& Castillo, 2007). Although a high Froude number has been related to reduced macroinvertebrate abundance (Brooks et al., 2005), the positive relationship with the abundance in our sampling sites could be explained by the trade-off between the good oxygen conditions and the energy budget to keep oxygen suitable habitats for macroinvertebrates. In this sense, extreme current velocity during floods leads to movement of the river bed with direct influence in the macroinvertebrate community (Death \& Zimmermann, 2005; Schwendel et al., 2010), but harsh hydraulic conditions do not promote the presence of high abundance of benthic macroinvertebrates.

According to Growns and Davis (1994), turbulent conditions are also necessary for the suspended food supply ingested by passive filterer macroinvertebrates. According to Walters and Post (2011) and Wills et al. (2006), a 90\% reduction in the available flow has been correlated with a decrease of filter feeding macroinvertebrates and an increase of predatory species. Although we did not detected changes in the functional feeding groups in our sampling sites, we expected a similar tendency in the more arid zones of Chile.

In our sampling sites, temporal variation of water abstraction and high flow period promotes a reset opportunity as the macroinvertebrate community recolonizes the sampling sites. During high flow periods, the principal mechanism for site recolonization is active drifting, widely

Table 5. Multiple linear regression and single best parameter for all the sampling sites during low flow, in central area of Chile (Itata basin).

\begin{tabular}{|c|c|c|c|c|c|c|c|c|c|c|c|c|}
\hline & \multicolumn{4}{|c|}{ Chemical parameters } & \multicolumn{5}{|c|}{ Physical parameters } & \multicolumn{3}{|c|}{ Statistical analysis } \\
\hline & OD & Temp & Cond & $\mathrm{pH}$ & Vel & Wid & Dep & $\mathrm{Fr}$ & $\begin{array}{l}\text { Wid/Dep } \\
\text { ratio }\end{array}$ & $\mathrm{R}^{2}$ & $p$ & Slope \\
\hline Richness & $x$ & & $\checkmark$ & & & & $X$ & $x$ & & 0.22 & $<0.001$ & - \\
\hline Abundance & & & & & $x$ & & $x$ & $\checkmark$ & & 0.20 & $<0.001$ & + \\
\hline Shannon & $\mathrm{X}$ & $x$ & & $x$ & $x$ & $\checkmark$ & $x$ & $x$ & $x$ & 0.19 & $<0.001$ & - \\
\hline Simpson & $x$ & $x$ & & $\checkmark$ & $x$ & & & $x$ & & 0.06 & 0.070 & - \\
\hline EPT & $x$ & & & $\checkmark$ & & $x$ & $x$ & $x$ & $x$ & 0.25 & $<0.001$ & - \\
\hline ChSIGNAL & $\checkmark$ & & & $x$ & & & & & & 0.37 & $<0.001$ & + \\
\hline
\end{tabular}

Note: Chemical parameters correspond to dissolved oxygen (OD), temperature (Temp), conductivity (Cond), and pH. Physical parameters are water velocity (Vel), wetted width (Wid), depth (Dep), number of Froude (Fr), wetted width/depth ratio (WW/Dep). The value of $R^{2}$ corresponds to the Adjusted $\mathrm{R}^{2}$. The statistical significance of the multiple regression model is denoted $(p)$. The significant parameters of multiple regression are marked $(X)$, as well as the best singular parameter $(\checkmark)$ 
Table 6. Summary of ADONIS test for statistical differences $(p<0.05)$ in the macroinvertebrate assemblage between reach sections in low and high flow sampling dates at Itata basin, Chile.

\begin{tabular}{lcccccccc}
\hline & \multicolumn{3}{c}{ October 2012} & & \multicolumn{2}{c}{ December 2012} & & \multicolumn{2}{c}{ March 2013 } \\
\cline { 2 - 3 } & $\mathrm{R}^{2}$ & $p$ & & $\mathrm{R}^{2}$ & $p$ & & $\mathrm{R}^{2}$ & $p$ \\
\hline Before-After (BA) & 0.107 & 0.001 & & 0.085 & 0.013 & & 0.104 & 0.001 \\
Control-Impact (Cl) & 0.029 & 0.003 & & 0.027 & 0.001 & & 0.009 & 0.474 \\
BA x Cl & 0.028 & 0.003 & & 0.026 & 0.022 & & 0.009 & 0.436 \\
\hline
\end{tabular}

used for the environmental assessment of the flow disturbance and river health (Death et al., 2009; Dewson et al., 2007b; James et al., 2009). In Chile, active drifting behavior is related to a circadian cycle (Figueroa et al., 2000), but more information is required regarding this dispersal mechanism as a functional bioindicator technique.

In this study, we did not detect statistical differences in the abundance or family richness indicators. However, the presence of statistical differences in the Shannon and Simpson indices for the accumulative abundance of benthic macroinvertebrates could reflect some sensitive responses to low flow conditions. In this sense, EPT families were defined as a good bioindicator in controlled (Death et al., 2009) or non controlled water withdrawals (Wills et al., 2006). In contrast, other studies determined the importance of specific habitat characteristics in order to detect environmental impacts through the EPT index (McKay \& King, 2006)

The use of biotic indices is a common practice to determine the environmental impacts on surface waters (Bonada et al., 2006; Rosenberg \& Resh, 1993). In Chile, the CHSignal demonstrates sensibility to water pollution in the semiarid rivers of northern Chile (Alvial et al., 2012) or in the Chillán River, a tributary of the Itata River (Figueroa et al., 2007). Similar trends were determined for other biotic indices like RIVPACS (Armitage \& Petts, 1992) or AUSRIVAS (Chessman et al., 2010).

We believe that the communities in the study area have suffered this type of impact for many years, so they have developed strategies to survive in adverse environmental conditions (Miller et al., 2007). In Mediterranean climate areas, seasonal predictable flow variations are closely related to macroinvertebrate biological or behavioral characteristics (Bonada et al., 2007), which give us the opportunity to record the magnitude of water abstraction (Dolédec \& Statzner, 2010; Menezes et al., 2010). In contrast, Walters and Post (2011) indicated that trait and classical taxonomic approach have the same power to detect habitat changes in low flow condition, but they do not discard evaluating specific traits like high crawling or armoring and resistance characteristics of macroinvertebrates. In Chile, the scarcity of available biological and taxonomic information regarding several macroinvertebrates families limits the improvement of bioindicator techniques (Stark et al., 2009). For example, the Gripopterygidae family has $55 \%$ undetermined species (Vera \& Camousseight, 2006), but Growns and Davis (1994) determined positive correlation of this family with the Froude number in Australian rivers. In addition, the conservation of endemic macroinvertebrates in low order rivers of Mediterranean Chile requires bioindicator techniques to be improved in accordance to the expected low rainfall and increased temperature (Figueroa et al., 2013; Pedreros et al., 2013).

\section{ACKNOWLEDGMENTS}

The preparation of this document was possible with partial support from Projects No. 212310060-10 DIUC, University of Concepción and FONDAP CRHIAM No. 15130015, CONICYT, Chile. The manuscript forms part of Meyer Guevara's PhD thesis, supervised by R. Figueroa. Partial studies support was given by MICIT-Costa Rica and OAS Scholarship for Graduate Studies.

\section{REFERENCES}

Ahearn, D., R. Sheibley \& R. Dahlgren. 2005. Effects of river regulation on water quality in the lower Mokelumne River, California. River Research and Applications 21 (6): 651-670. D0I: 10.1002/rra.853

Alvial, I. E., D. H. Tapia, M. J. Castro, B. C. Duran \& C. A. Verdugo. 2012. Analysis of benthic macroinvertebrates and biotic indices to evaluate water quality in rivers impacted by mining activities in northern Chile. Knowledge and Management of Aquatic Ecosystems 407 (1): DOI: 10.1051/kmae/2012027

Allan, J. \& M. CASTILLO. 2007. Stream Ecology. Structure and function of running waters. Springer, Netherlands. $436 \mathrm{p}$.

Anderson, M. J. 2001. A new method for non-parametric multivariate analysis of variance. Austral Ecology 26 (1): 32-46. D0I: 10.1111/ j.1442-9993.2001.01070.pp.x

Anderson, M. J., K. E. Eluingsen \& B. H. McArdle. 2006. Multivariate dispersion as a measure of beta diversity. Ecology Letters 9 (6): 683-693. DOI: 10.1111/j.1461-0248.2006.00926.x

Andreoli, A., L. Mao, A. Iroumé, J. L. Arumí, A. Nardini, R. Pizarro, D. CaamaÑO, C. MeIER \& 0. Link. 2012. The need for a hydromorphological approach to Chilean river management. Revista Chilena de Historia Natural 85: 339-343.

Armitage, P. D. \& G. E. Petts. 1992. Biotic score and prediction to assess the effects of water abstractions on river macroinvertebrates for conservation purposes. Aquatic Conservation: Marine and Freshwater Ecosystems 2 (1): 1-17. D0I: 10.1002/aqc.3270020102

Bonada, N., N. Prat, V. H. Resh \& B. Statzner. 2006. Developments in aquatic insect biomonitoring: A comparative analysis of recent approaches. Annual Review of Entomology 51: 495-523. D0I: 10.1146/ annurev.ento.51.110104.151124

BonADA, N. \& V. H. ReSH. 2013. Mediterranean-climate streams and rivers: geographically separated but ecologically comparable freshwater systems. Hydrobiologia 719 (1): 1-29. DOI: 10.1007/s10750-0131634-2

Bonada, N., M. Rieradevall \& N. Prat. 2007. Macroinvertebrate community structure and biological traits related to flow permanence in a Mediterranean river network. Hydrobiologia 589 (1): 91-106. D0l: 10.1007/s10750-007-0723-5

Brooks, A. J., T. I. M. Haeusler, I. Reinfelds \& S. Williams. 2005. Hydraulic microhabitats and the distribution of macroinvertebrate assemblages in riffles. Freshwater Biology 50 (2): 331-344. DOI: 10.1111/j.13652427.2004.01322.x 
Brown, P. D., D. Wooster, S. L. Johnson \& S. J. DeBano. 2012. Effects of water withdrawals on macroinvertebrate emergence: Unexpected results for three holometabolous species. River Research and Applications 28 (3): 347-358. D0I: 10.1002/rra.1460

Bunn, S. E. \& A. H. Arthington. 2002. Basic principles and ecological consequences of altered flow regimes for aquatic biodiversity. Environmental Management 30 (4): 492-507. D0I: 10.1007/s00267002-2737-0

Caruso, B. S. 2002. Temporal and spatial patterns of extreme low flows and effects on stream ecosystems in Otago, New Zealand. Journal of Hydrology 257 (1-4):115-133. D0I: 10.1016/S00221694(01)00546-7

Chessman, B. C. 2003. New sensitivity grades for Australian river macroinvertebrates. Marine and Freshwater Research 54 (2): 95-103. DOI: $10.1071 / \mathrm{mf0} 2114$

Chessman, B. C., H. A. Jones, N. K. Searle, I. 0. Growns \& M. R. Pearson. 2010. Assessing effects of flow alteration on macroinvertebrate assemblages in Australian dryland rivers. Freshwater Biology 55 (8): 1780-1800. DOI: 10.1111/j.1365-2427.2010.02403.x

Chessman, B. C., M. J. Royal \& M. Muschal. 2011. The challenge of monitoring impacts of water abstraction on macroinvertebrate assemblages in unregulated streams. River Research and Applications 27 (1): 76-86. DOl: 10.1002/rra.1340

Dahm, C. N., M. A. Baker, D. I. Moore \& J. R. Thibault. 2003. Coupled biogeochemical and hydrological responses of streams and rivers to drought. Freshwater Biology 48 (7): 1219-1231. D0l: 10.1046/j.1365-2427.2003.01082.x

DeAtH, R. G. 2010. Disturbance and riverine benthic communities: What has it contributed to general ecological theory? River Research and Applications 26 (1): 15-25. DOI: 10.1002/rra.1302

Death, R. G., Z. S. Dewson \& A. B. W. James. 2009. Is structure or function a better measure of the effects of water abstraction on ecosystem integrity? Freshwater Biology 54 (10): 2037-2050. D0I: 10.1111/j.1365-2427.2009.02182.x

Death, R. G. \& E. M. Zimmermann. 2005. Interaction between disturbance and primary productivity in determining stream invertebrate diversity. Oikos 111 (2): 392-402. DOI: 10.1111/j.00301299.2005.13799.x

Debels, P., R. Figueroa, R. Urrutia, R. Barra \& X. Niell. 2005. Evaluation of water quality in the Chillan River (Central Chile) using physicochemical parameters and a modified Water Quality Index. Environmental Monitoring and Assessment 110 (1-3): 301-322. DOI: 10.1007/ s10661-005-8064-1

Dewson, Z., A. B. W. James \& R. G. Death. 2007a. A review of the consequences of decreased flow for instream habitat and macroinvertebrates. Journal of the North American Benthological Society 26 (3): 401-415. DOI: 10.1899/06-110.1

Dewson, Z. S., A. B. W. James \& R. G. Death. 2007b. Invertebrate responses to short-term water abstraction in small New Zealand streams. Freshwater Biology 52 (2): 357-369. D0I: 10.1111/j.13652427.2006.01682.x
Dewson, Z. S., A. B. W. James \& R. G. Death. 2007c. Stream ecosystem functioning under reduced flow conditions. Ecological Applications 17 (6): 1797-1808. DOI: 10.1890/06-1901.1

Di CASTRI, F. \& E. Hajek. 1976. Bioclimatología de Chile. 1a ed. Universidad Católica de Chile, Santiago. 160 p.

Dolédec, S. \& B. Statzner. 2010. Responses of freshwater biota to human disturbances: contribution of J-NABS to developments in ecological integrity assessments. Journal of the North American Benthological Society 29 (1): 286-311. DOI: 10.1899/08-090.1

Domínguez, E., C. Molineri, M. L. Pescador, M. D. Hubbard \& C. Nieto, 2006. Ephemeroptera of South America. In: Adis, J., J. R. Arias, S. Golovatch, K. M. Wantzen \& G. Rueda-Delgado (Eds.) Aquatic biodiversity of Latin America. Vol 5. Pensoft, Sofia-Moscow. 646 p.

Downes, B. J. 2002. Monitoring ecological impacts: concepts and practice in flowing waters. 1st ed. Cambridge University Press, Cambridge. $452 \mathrm{p}$.

Dudgeon, D., A. H. Arthington, M. 0. Gessner, Z. I. Kawabata, D. J. Knowler, C. Lévêque, R. J. Naiman, A. H. Prieur-Richard, D. Soto, M. L. J. Stiassny \& C. A. Suluivan. 2006. Freshwater biodiversity: importance, threats, status and conservation challenges. Biological Reviews 81 (2): 163-182. DOI: $10.1017 / \mathrm{s} 1464793105006950$

Dufrene, M. \& P. Legendre. 1997. Species Assemblages and Indicator Species: The Need for a Flexible Asymmetrical Approach. Ecological Monographs 67 (3): 345-366. DOl: 10.2307/2963459

Eaton A. D., L. S. Clesceri, E. W. Rice \& A. E. Greenberg. 2005. Standard methods for the examination of water and wastewater. American Public Health Association (APHA). Washington, D. C. 1400 p.

Figueroa, R., E. Araya \& C. Valdovinos. 2000. Deriva de macroinvertebrados en un sector de rithron: río Rucue, Chile Centro Sur. Boletín de la Sociedad de Biológia de Concepción 71: 23-32.

Figueroa, R., N. Bonada, M. Guevara, P. Pedreros, F. Correa-Araneda, M. E. Díaz \& V. H. Ruiz. 2013. Freshwater biodiversity and conservation in mediterranean climate streams of Chile. Hydrobiologia 719 (1): 269-289. DOI: 10.1007/s10750-013-1685-4

Figueroa, R., A. Palma, V. Ruiz \& X. Niell. 2007. Comparative analysis of biotic indexes used to evaluate water quality in a Mediterranean river of Chile: Chillan River, VIII Region. Revista Chilena de Historia Natural 80 (2): 225-242. D0I: 10.4067/s0716-078x2007000200008

FriedL, G. \& A. Wüest. 2002. Disrupting biogeochemical cycles. Consequences of damming. Aquatic Sciences 64 (1): 55-65. D0I: 10.1007/s00027-002-8054-0

Garcia, A., K. Jorde, E. Habit, D. Caamaño \& 0. Parra. 2011. Downstream environmental effects of dam operation: changes in habitat quality for native fish species. River Research and Applications 27 (3): 312327. DOI: 10.1002/rra.1358

GAuCH, H. G. 1982. Multivariate analysis in community ecology. Cambridge University Press, Cambridge, UK. 298 p.

Gore, J. A., 2007. Discharge Measurements and Streamflow Analysis. In: Hauer, F. R. \& G. A. Lamberti (Eds.) Methods in Stream Ecology. Elsevier, Amsterdam, pp. 51-77. 
Growns, I. 0. \& J. A. Davis. 1994. Longitudinal changes in near-bed flows and macroinvertebrate communities in a Western Australian stream. Journal of the North American Benthological Society 13 (4): 417-438. DOI: $10.2307 / 1467842$

Habit, E., M. C. Belk \& 0. ParRa. 2007. Response of the riverine fish community to the construction and operation of a diversion hydropower plant in central Chile. Aquatic Conservation: Marine and Freshwater Ecosystems 17 (1): 37-49. D0I: 10.1002/aqc.774

Habit, E., M. C. Belk, R. C. Tuckfield \& 0. Parra. 2006. Response of the fish community to human-induced changes in the Biobio River in Chile. Freshwater Biology 51 (1): 1-11. D0I: 10.1111/j.13652427.2005.01461.x

James, A. B. W., Z. S. Dewson \& R. G. Death. 2009. The influence of flow reduction on macroinvertebrate drift density and distance in three New Zealand streams. Journal of the North American Benthological Society 28 (1): 220-232. DOI: 10.1899/07-146.1

Larned, S. T., T. Datry, D. B. Arscott \& K. Tockner. 2010. Emerging concepts in temporary-river ecology. Freshwater Biology 55 (4): 717-738. DOI: 10.1111/j.1365-2427.2009.02322.x

McKay, S. F. \& A. J. KIng. 2006. Potential ecological effects of water extraction in small, unregulated streams. River Research and Applications 22 (9): 1023-1037. DOI: 10.1002/rra.958

Menezes, S., D. J. Baird \& A. Soares. 2010. Beyond taxonomy: a review of macroinvertebrate trait-based community descriptors as tools for freshwater biomonitoring. Journal of Applied Ecology 47 (4): 711719. D0l: $10.1111 / \mathrm{j} .1365-2664.2010 .01819 . x$

Miller, S. W., D. Wooster \& J. LI. 2007. Resistance and resilience of macroinvertebrates to irrigation water withdrawals. Freshwater Biology 52 (12): 2494-2510. DOI: 10.1111/j.1365-2427.2007.01850.x

Myers, N., R. A. Mittermeier, C. G. Mittermeier, G. A. B. Da Fonseca \& J. Kent. 2000. Biodiversity hotspots for conservation priorities. Nature 403 (6772): 853-858. DOI: 10.1038/35002501

Palma, A. \& R. Figueroa. 2008. Latitudinal diversity of Plecoptera (Insecta) on local and global scales. Illiesia 4 (8): 81-90.

Pedreros, P., M. Guevara, R. Figueroa, A. Araneda, A. Sther, 0. Link \& R. UrruTIA. 2013. Comportamiento térmico en ríos mediterráneos andinos de la zona centro-sur de Chile. Limnetica 32 (1): 87-96.

Pizarro, J., P. M. Vergara, J. A. Rodriguez, P. A. Sanhueza \& S. A. Castro. 2010. Nutrients dynamics in the main river basins of the centre-southern region of Chile. Journal of Hazardous Materials 175 (1-3): 608-613. D0I: 10.1016/j.jhazmat.2009.10.048

Poff, N. L., J. D. Allan, M. B. Bain, J. R. Karr, K. L. Prestegaard, B. D. Richter, R. E. Sparks \& J. C. Stromberg. 1997. The natural flow regime. BioScience 47 (11): 769-784. DOI: 10.2307/1313099

RosenberG, D. M. \& V. ReSH, 1993. Freshwater biomonitoring and benthic macroinvertebrates. In: Resh, V. \& H. K. Jackson (Eds.) Rapid as- sessment approaches to biomonitoring using benthic macroinvertebrates. Chapman \& Hall. London, pp. 195-233.

Von Schiller, D., V. Acuña, D. Graeber, E. Martí, M. Ribot, S. Sabater, X. TimoNER \& K. TOCKNER. 2011. Contraction, fragmentation and expansion dynamics determine nutrient availability in a Mediterranean forest stream. Aquatic Sciences 73 (4): 485-497. D0l: 10.1007/s00027011-0195-6

Schwendel, A. C., R. G. Death \& I. C. Fuller. 2010. The assessment of shear stress and bed stability in stream ecology. Freshwater biology 55 (2): 261-281. DOI: 10.1111/j.1365-2427.2009.02293.x

Stanford, J. A., M. S. Lorang \& R. F. Hauer. 2005. The shifting habitat mosaic of river ecosystems. Internationale Vereinigung fur Theoretische und Angewandte Limnologie Verhandlungen 29 (1): 123-136.

Stark, B. P., C. Froehlich \& M. Zúñiga. 2009. South American Stoneflies (Plecoptera). 3rd ed. Pensoft, Sofia-Moscow. 154 p.

Townsend, C. R., M. R. Scarsbrook \& S. Dolédec. 1997. The intermediate disturbance hypothesis, refugia, and biodiversity in streams. Limnology and Oceanography 42 (5): 938-949. D0I: 10.4319/ 10.1997.42.5.0938

Urrutia, R., 0. Parra, F. Cruces, A. Araneda, R. Barra, R. Figueroa \& H. Cid, 2009a. Calidad de Agua del río Itata. In: Parra, O., J. C. Castilla, H. Romero, R. Quiñones \& A. Camaño (Eds.) La cuenca hidrográfica del Río Itata aportes científicos para su gestión sustentable. Editorial Universidad de Concepción, Concepción, Chile, pp. 23-43.

Urrutia, R., 0. Parra, F. Cruces, A. Araneda, R. Barra, R. Figueroa \& H. Cid, 2009b. Calidad de Agua del río Itata. In: Parra, 0., J. C. Castilla, H. Romero, R. Quiñones \& A. Camaño (eds) La cuenca hidrográfica del río Itata Aportes científicos para su gestión sustentable. Editorial Universidad de Concepción, Concepción, pp. 89-99.

Valdovinos, C., 2008. Invertebrados dulceacuícolas. In: CONAMA (Ed.) Biodiversidad de Chile Patrimonio y Desafíos. Ediciones Santiago de Chile. Santiago, Chile, pp. 202-224.

Venables, W. N. \& B. D. Ripley. 2002. Modern Applied Statistics with S. 4th Ed. Springer, New York. 504 p.

Vera, A. \& A. Camousseight. 2006. Estado de conocimiento de los Plecopteros de Chile. Gayana 70 (1): 57-64. D0I: 10.4067/s071765382006000100010

Vörösmarty, C. J., P. B. Mclntyre, M. 0. Gessner, D. Dudgeon, A. Prusevich, P. Green, S. Glidden, S. E. Bunn, C. A. Sullivan, C. R. Liermann \& P. M. Davies. 2010. Global threats to human water security and river biodiversity. Nature 467 (7315): 555-561. DOI: 10.1038/nature09440

Walters, A. W. \& D. M. Post. 2011. How low can you go? Impacts of a low-flow disturbance on aquatic insect communities. Ecological Applications 21 (1): 163-174. DOI: 10.1890/09-2323.1

Wills, T. C., E. A. Baker, A. J. Nuhfer \& T. G. Zorn. 2006. Response of the benthic macroinvertebrate community in a northern Michigan stream to reduced summer streamflows. River Research and Applications 22 (7): 819-836. D0l: 10.1002/rra.938 